\title{
AZ MTA REGIONÁLIS TUDOMÁNYOS BIZOTTSÁGA HÍREI
}

\section{RÉGIÓK KIALAKULÁSA ÉS VÁLTOZÁSA: VÉLETLEN VAGY SZÜKSÉGSZERÜSÉG?}

\author{
(Genesis and Change of the Regions: Chance or Necessity?)
}

\author{
Akadémiai székfoglaló előadás \\ PROF. DR. BENEDEK JÓZSEF \\ „Babes-Bolyai” Tudományegyetem, Földrajztudományi Kar, \\ Társadalomföldrajzi Tanszék
}

Több mint tíz éve foglalkoztat a társadalom egyik alapvető jellegzetességének, a térbeliségnek a vizsgálata (Benedek 1998; 2000; 2001; 2002; 2003; BenedekJordan 2007; Benedek 2008a, 2008b). Úgy gondolom, hogy a fenti kérdéskörnek egyik leglátványosabb és célravezetőbb megközelítési lehetőségét jellegzetes térbeli képződmények, a régiók kialakulásának és müködésének elemzése kínálja. Tanulmányaim lényegi következtetése, hogy a tér egymaga mint relatív fogalom egy módon operacionalizálható: régiók és helyek lehatárolásával és elemzésével. Előadásom vezérfonala a fenti gondolathoz igazodik, célja a térbeliség konkrét megjelenési formáinak elemzése, különböző regionalizálási módozatok alapján.

\section{Régióképzödés a modern regionális földrajz megközelitésében}

A társadalmi konstruktivizmus szemléletében a régió társadalmi, gazdasági és politikai interakciók hálózataiból épül fel. Ezek szerint a társadalmak ugyanúgy létrehozzák saját földrajzukat, mint saját történelmüket is, azaz saját térképzeteiket éppúgy, mint időbeosztásukat. Ebből adódóan a régió is egy társadalmi konstrukció, azaz intézmények és cselekvő egyének által kialakított térbeli képződmény, ellentétben a kvantitatív paradigma és a tradicionális regionális földrajz realista régiófogalmával, amely szerint a régió objektív, tudattól és társadalomtól független, abszolút léttel rendelkező entitás.

A regionális kutatások konstruktivista irányzatai közül kiemelkedik az új vagy modern regionális földrajz (new regional geography), amely néhány alapvető újí- 
tással járult hozzá a régiók kialakulására vonatkozó vitában (Pred 1994; Thrift 1996; Werlen 1997; Gregory 1998; Allen-Massey-Cochrange 1998):

- a régió a társadalmi kapcsolatok közege és ugyanakkor eredménye is;

- a régió a történelem terméke, amelynek kialakulása nem anyagi folyamatnak, hanem jellegzetes, úgymond strukturáló társadalmi kapcsolatok és kölcsönhatások eredményének tekinthető. A történelem, és ezzel tulajdonképpen a véletlennek a beemelése a regionális kutatásokban elsősorban Allan Pred „helyelméletének" érdeme. Szerinte a régió a gazdaság, politika, nemek, osztály és etnicitás történetének összetett eredménye, amely két alapvető társadalmi folyamat során alakul ki: a tér kisajátítása és a természet átalakítása során. Allen-Doreen-Massey-Cochrange 1998-ban kiadott nagyhatású könyvükben (,Rethinking the region”) a régió konceptualizációját szoros összefüggésbe hozzák a tér és hely konceptualizációjával, azt a provokációnak is számítható gondolatot fogalmazván meg, hogy a régiókat a térbeli-társadalmi kapcsolatok és az ezekről alkotott elbeszélések (narrációk) építik fel. A régió nem külső, objektív realitás, amelyet csupán fel kell fedezni, hanem a humán alany jellegzetes konstrukciója.

- további fontos újítása a modern regionális földrajznak arra vonatkozik, hogy a regionalizációnak létezik egy finalitása, egy külső ok hozza létre, azaz nem belülről determinált. Ez azt jelenti, hogy nem léteznek „reális” régiók, hanem csak a regionalizálás céljából meghatározott régiók, függetlenül attól, hogy ez interszubjektíven konstituálódik vagy objektív-pragmatikus módon.

- az új regionális földrajz további novumának számított a regionális identitáskutatás. Legjelentősebb képviselői (H. H. Blotevogel, G. Heinritz, H. Popp és $J$. Pohl) szerint egy ilyen irányú regionális kutatás aktívan járulhatna hozzá bizonyos össztársadalmi problémák megoldásához, illetve a kultúrgeográfiai térfelosztások kidolgozásához (Blotevogel-Heinritz-Popp 1987; Pohl 1993; Blotevogel 1996). Szerintük az identitástudathoz tartozik a tér reprezentációja is, ami interszubjektíven/kollektíven alakul ki. Ez azt jelenti, hogy minden egyén kialakít egy képet arról a régióról, amelyben él, vagy más régiókról, ez a folyamat viszont meghatározóan kötődik a többi egyénnel kialakított interakciókhoz és ennek függvényében kap tartalmat, illetve módosítja tartalmát. Ebben a megközelítésben megfogalmazódott egy sor központi kérdés, amelyre az eddigi kutatások még nem találtak általánosan elfogadható és megnyugtató válaszokat:

- hogyan alakulnak ki a térreprezentációk regionális léptékben;

- hogyan változnak, esetleg hogyan tünnek el bizonyos regionális térreprezentációk;

- milyen kommunikációs környezet, forma és milyen szereplők fontosak a térreprezentációk kialakulásában és változásában;

- hogyan határolódnak el az identitástudat térbeli megfelelői. 


\section{Regionalizálási módozatok}

Alapul véve a fentebb röviden bemutatott központi fogalmakat (dialektikus jelleg, történelem és identítás, régióalkotás célfüggősége), és figyelembe véve három további központi elemet: „regionalizáló” intézmények, régióalkotási mechanizmusok, létrejött régiók jellege, a továbbiakban a regionalizálási módozatok három típusát különböztetem meg:

- normatív-formális regionalizálás: a regionalizálás intézményes hálózatára vonatkozik és ennek legjobb példáját a társadalmak (államok) területiadminisztratív felosztása alkotja;

- szimbolikus-informális regionalizálás: a köztudat szintjén, azaz a szubjektumok szintjén lezajló regionalizálás, amely kultúra- és csoportjellegü;

- pozitivista regionalizálás: a tudomány által alkalmazott regionalizálásra és az általa létrehozott terekre vonatkozik.

Ez a felosztás nem jelenti azt, hogy a tudomány csupán az utóbbi regionalizálási típussal foglalkozik. Különbséget kell tennünk a regionalizálás mint régiólehatárolási, régióépítési módszer és az empirikus regionálgeográfiai analízis között. Az utóbbi egyértelmủen mind a három módozattal lehatárolt régiótípusra kiterjed. Ebben a megközelítésben nyilvánvalóan a földrajz, a tudomány általában, mint társadalmi intézmény, létrehozza saját tereit (,regionalizál”), rendszerint egy pozitivista világszemlélet alapján, amely feltételezi, hogy létezik egy tudattól független, külső valóság, amelyet a tudomány objektíven feltárhat. Egyértelműen a másik két, a formális intézmények és a társadalmi egyének térkötődöttségét tükröző regionalizálás régióképződményei a tudomány tárgyát képzik, de ezek nem a tudomány mint társadalmi intézmény jellegzetes képződményei.

A regionalizálás abból az alapfeltételezésből indul ki, hogy a megfigyelt tartalmak között összefüggés létezik, tehát bizonyítékokat hozhatunk egy régió létezésére. Ilyen bizonyíték a formális regionalizálás esetében a jogszabályok összessége, amelyek intézményesült régiók határait, intézményeit és müködési mechanizmusait határozzák meg, illetve az informális regionalizálás esetében a regionális identitástudat, a régióhoz tartozás szimbolikus jelentéstartalma. Ehhez adódnak a tudomány regionalizálási módszerei, amelyek a realitást próbálják tudományosan, azaz szisztematikusan és elméletorientáltan magyarázni.

\section{Normatív-formális (intézményesült) regionalizálás}

A terület, a tér a modern államok alapvetö komponense. Ennek a területnek a közigazgatása, a hatalomnak az egész területen érvényes gyakorlása a tér vagy terület regionalizálása alapján történik, ami nem jelent egyebet, mint az államot alkotó terület jogrendszer által biztosított normatív jellegü téregységekre történő felbontása. A normatív-formális regionalizálás az állam intézményeinek hatáskörébe tartozik. 
Ezek közül ebben a vonatkozásban különös jelentőség a politikai szférának jut. Itt születnek meg azok a döntések, amelyek a teret regionalizálják, azaz felosztják, lehatárolják különböző szintű egységek formájában.

Függetlenül a létrehozott téregységek típusától, a normatív-formális regionalizálás során vegyes lehatárolási kritériumokat használunk, amelyek magukban foglalnak mind a hasonlóság, mind a kapcsolatok elvén alapuló kritériumokat is, a helyi és regionális földrajzi, történelmi, kulturális és gazdasági adottságoknak és sajátosságoknak megfelelően. Ehhez adódnak még a politikai jellegű kritériumok, amelyek rendszerint meghatározóak.

A normatív-formális regionalizálás bizonyos korlátokat szab az egyéni célok elérésére felhasznált eszközök hozzáférhetőségét illetően. Ennek megfelelően a közigazgatási, tervezési vagy bármilyen más típusú normatív-formális régió müködését szabályozó törvények és rendelkezések a cselekvések kontextusát alkotják, a térstruktúrák részei, amelyek bizonyos cselekvéseket lehetővé tesznek, illetve másokat megakadályoznak.

A program-régiók és tervezési régiók (Weichart 1996) mellett, amelyek rendszerint a területtervezés és a regionális politika célrégiói, megkülönböztetünk még egy alapvető normatív-formális téregységet, a területi-közigazgatási egységeket. Ezek határait, müködésüket törvények, szabályozzák. Ennek megfelelően, ha különböző társadalmak többszintes adminisztratív térfelosztását összehasonlítjuk, nagyon heterogén képet kapunk, ami a szintek számát, a téregységek nagyságát, népességét, illetve különböző szintek müködési mechanizmusait és kompetenciáit illeti. Szükségszerüen minden állam legalább két közigazgatási szintet határol le. Az utóbbi évtizedek regionális mozgalmainak megerősödése, illetve az EU követelései nyomán több európai ország háromszintes területi-adminisztratív rendszert dolgozott ki.

Ugyanakkor az adminisztratív-területi felosztás nagymértékben meghatározza a pozitivista regionalizálást is, mert a területi statisztikák a meglévő közigazgatási egységekre épülnek fel. Az EU regionális politikája és statisztikai térrendszere (NUTS) hatására a tagállamok és a csatlakozni kívánó államok egy harmadik (regionális) szintet is létrehoztak, nagyon eltérő kompetenciákkal, a föderalisztikus rendszer törvényhozó regionális testületeitől (Németország, Ausztria, Spanyolország) egészen a centralizált államok többnyire kirakat jellegü regionális szintjéig (Románia).

\section{Pozitivista regionalizálás}

Fő szereplöje a tudomány mint társadalmi intézmény, amely sajátos régiókat hoz létre. A lényeges különbség a normatív-formális regionalizáláshoz képest abban rejlik, hogy a tudomány régióképződményei nem koercitív, azaz nem norma jellegüek a társadalom számára. Nyilván az más kérdés, hogy a tudomány által meghatározott régiók milyen mértékben befolyásolják a normatív szféra regionalizálását. Az utóbbi, elsősorban a területi-közigazgatási egységek létrehozásakor bizonyos mértékben a 
tudományos eredményekre épít vagy ezeket politikai célok legitimálására használja fel. További különbségek a regionalizálási eszközök használatában, illetve a regionalizálás céljainak meghatározásában jelennek meg; míg a normatív-formális regionalizálás kemény, koercitív eszközöket használ állami funkciók racionális ellátása céljából, addig a pozitivista regionalizálás puha eszközöket alkalmaz a valóság tudományos, szisztematikus magyarázására.

A pozitivista regionalizálás célja a valóság szisztematikus, elméleti alapú rendezése, illetve bizonyos részdoméniumokra érvényes törvényszerüségek felfedezése és magyarázása. Rendszerint a lehatárolási kritériumok és az alkalmazott módszertan alapján ez a regionalizálási módozat két régiótípust határoz meg: homogén régió (struktúra régió) és funkcionális régió (polarizált vagy nodális régió).

\section{Homogén (struktúra) régió}

A homogén régiók lehatárolása a hasonlóság elvén alapszik, bizonyos struktúrajelzőket vagy ezek index formájában történő aggregációját használva fel. Ez azt jelenti, hogy a homogén régiót az alkotó térstruktúra egyedisége határozza meg. Például a Mezőség egy homogén régió, amely határozottan lehatárolható a szomszédos régióktól bizonyos sajátos, a szomszédos régiókban hiányzó tulajdonságok, struktúrák alapján: városok hiánya, településeket alkotó háztartások magas fokú szétszóródása a térben, a jó minőségü altalajvíz hiánya, elörehaladott aridizáció stb. A lehatárolásnál figyelembe vehetünk egy vagy akár több struktúrajelzőt is, illetve az utóbbi esetben ezek kombinációját komplex mutatók formájában (pl. a ruralitási index). Attól függően, hogy milyen struktúrajelzőket használunk a lehatárolásnál, illetve hogy milyen doméniumot (település, gazdaság, természet stb.) elemzünk a lehatárolt egységen belül, több homogén vagy struktúra régiót különböztetünk meg: természetföldrajzi régiók, agrárrégiók, ipari régiók, város régiók, turisztikai régiók stb.

A homogén régiók lehatárolásával kapcsolatban felmerülő problémák közül kettőt említünk meg (Weichart 1996):

- a regionalizálást erősen befolyásolja az elemzett ismérvek (tulajdonságok) területi vonatkoztatási egységeinek kiválasztása. Ez az ismérvek jellegétől is függ, például népességi adatokat csak község-, legjobb esetben településszinten tudunk elemezni. Mindenesetre a kiválasztott területegység (legyen az adminisztratív vagy statisztikai jellegü) meghatározza a regionalizáció eredményét;

- a regionalizálást meghatározza az értékskála felépítése, azaz az értékintervallumok és az ezeknek megfelelő kategóriák kiválasztása. Erre a célra statisztikai eljárásokat használunk, de tudjuk, hogy a statisztika is csupán előírásokat fogalmaz meg, nem pontos „recepteket” az értékintervallumok szerkesztésére (pl. legyen elegendő esetünk minden intervallumban, anélkül, hogy pontosan megtudnánk, mennyi stb.). 
A fentiekből következik, hogy a homogenitás elvén nyugvó regionalizálás befolyásolja a módszernek az eredményeit is, vagy más szóval: a létrejött régiók jelentős mértékben a módszernek az eredményei, módszertani képződmények.

\section{Funkcionális (polarizált) régió}

A polarizált vagy funkcionális régiót a polarizáló központ és a polarizált részek közötti kapcsolatrendszer határozza meg. A polarizált régiók funkcionális központperiféria típusú kapcsolatrendszer lehatárolása alapján kerülnek elemzés alá. Az utóbbi során rendszerint megállapítják a polarizáló központokat (csomópontok) és az ezeket összekötő fejlődési tengelyeket. A funkcionális lehatárolásban általában megelégednek azzal, hogy releváns polarizáló pontoknak (rendszerint városok) funkcionális tereket osztanak le.

A funkcionális kapcsolatok nagyon változékonyak a homogén (strukturális) terekhez képest, mivel a központi intézmények állandóan változnak a gazdaság-politikai kontextus függvényében. A fontosabb polarizációs pontok átvészelik a kisebb vagy nagyobb konjunktúraváltozásokat, mert már létrejöttüket, illetve helyüket a regionális településrendszerben lokalizációjuk minősége és a történelmileg kialakult hatalmi viszonyok határozzák meg.

Módszertanilag a polarizált régiók lehatárolása azon alapszik, hogy kvantifikáljuk és mérjük a különbözö központok-vonzáskörzetek között kialakult kapcsolattípusokat. Pontosabban ezeknek három dimenzióját mérik:

- egyes kapcsolattípusok gyakorisága,

- a kapcsolattípusok intenzitása,

- a kapcsolatok irányítottsága.

Miután ez megtörtént, vizualizáljuk minden kapcsolattípus rádiuszát, azaz vonzáskörzetét, végül pedig a vonzáskörzetek fedéséböl lehatároljuk a régió magját, azt a részt, ahol minden vonzáskörzet areálja fedi egymást. Rendszerint a magterületet egy átmeneti sáv veszi körül, ahol a kapcsolatok ritkábbak és alacsonyabb intenzitással lépnek fel. Végül egy periferikus sáv következik, amelyben csak kis számú és gyenge intenzitású kapcsolat van jelen.

Mint a lehatárolási eljárásnál láthattuk, a funkcionális régió, akárcsak a homogén régió, erősen függ a lehatárolás módszerétől, attól, hogy egyes szerzők miként értelmeznek bizonyos kapcsolattípusokat, illetve milyen határértékeket használnak fel az interakciók gyakoriságának és intenzitásának mérésére. Ezért állíthatjuk abban az esetben is, hogy a lehatárolt régiók módszertani képződmények. A pozitivista regionalizálással Weichart szerint (1996) a térrészeket perszonalizáljuk, amihez hozzáadhatjuk, hogy ez lényegében a cselekvő szereplők deperszonalizációját eredményezi. Mindez azt jelenti, hogy a regionalizáció során alapjában véve a népességre vagy egyes társadalmi csoportokra vonatkozó paramétereket használunk fel, amelyeket térbe vetítünk ki, különböző régiótípusok formájában. 


\section{Szimbolikus-informális regionalizálás}

A szimbolikus-informális regionalizálás a mindennapi térhasználók térfogalmait, regionális identitását, illetve azt a módozatot tükrözi, amellyel az egyének szimbólumokkal, jelentésekkel ruháznak fel helyeket, régiókat, térségeket.

A cselekvő egyének mindennapos rutinszerủ tevékenységeik során kialakítanak egy képet arról a régióról, amelyben élnek, illetve más, szomszédos vagy távolabbi régiókról. Más szóval a szimbolikus-informális regionalizálás során meghatározott régiók szociálpszichológiai konstrukciók, amelyek a modern regionális paradigma egyik jellegzetes kutatási tárgyát képezik. A regionális identitástudat, a különböző régiókról alkotott kép alapvetően közvetlen és közvetett tapasztalat során alakul ki. A második esetben a következő közvetítő csatornák alakítják ki és formálják újra a regionális ikonográfiákat:

- „mások” verbálisan közölt tapasztalatai,

- média (újság, TV, rádió, internet),

- szocializáció (család, iskola, munkahely),

- politikai diskurzus.

Az egyének életvilágát felölelő régióról kialakult identitáskép elsősorban a direkt tapasztalat eredménye, de nyilván fontos szerepet játszik a média és az iskolai szocializáció is. Az utóbbi esetében a legfontosabb identitásépítő eszköz a földrajz és a történelem. Ezen a ponton kapcsolódik a pozitivista és a normatív-formális regionalizálás a szimbolikus szinthez, ugyanis a tudomány által eszközölt realitásdiskurzusok - ebben az esetben a térről, a régióról - beépülnek az iskolai tankönyvekbe és bizonyos identitásképek folytonos újratermelését biztosítják. Ez azt jelenti, hogy a szimbolikus-informális regionalizálás mechanizmusát az iskola, mint a már említett regionalizálások legfontosabb identitásformáló eszköze, jelentősen befolyásolja. A szomszédos vagy távolabbi régiókról kialakult kép (itt már nem beszélhetünk identitástudatról) viszont rendszerint már csak másodlagosan közvetített és csak ritkábban a direkt tapasztalatok eredménye. Ebben az esetben a fejezet kezdetén felsorolt tényezők játsszák a fő szerepet. A tapasztalatok (direkt vagy indirekt) bizonyos anyagi jellegü elemek, a népesség, illetve a cselekvések értelmezésére vonatkoznak. Az anyagi és társadalmi valóság fent leírt mindennapos konceptualizálását reifikációnak nevezik (Weichart 1996). Ennek során a társadalmi szereplők bizonyos dolgok jellegzetességeit anyagi fogalmakká alakítják át. A népesség értelmezésében a hasonlóságokra és interakciókra figyelünk, ez pedig bizonyos sztereotípiák kialakulásához vagy újratermeléséhez vezet. Az így kialakult kollektív kép bizonyos régiókra vetítődik, amelyek ugyanakkor a személyes „én” és a szimbolikus „mi” projekciós felületei. A regionális identitás megörzésének egyik mechanizmusa az elzárkózás, amely elsősorban az etnikai tartalmú regionális identitások esetében rendkívül erős lehet.

A helynevek és régiónevek a nyelvidentitás helyeit alkotják, különböző vonatkozással: kulturális, vallásos, politikai, természeti. Például a Mezőség és a Nyírség 
természeti környezetet tükröző elnevezések, Normandia és Erdély történeti régiók, Párizs városrégió, a Massif Central geológusok által meghatározott régió, míg a Mezzogiorno a fejletlenség régiója. Mindegyik megtalálható a szimbolikus-informális regionalizálásban, annak ellenére, hogy eredetileg nem ennek a jellegzetes konstrukciói voltak, hanem a tudományos és politikai diskurzus és információ közvetítési csatornáinak, elsősorban az iskolának és a médiának hatására alakultak ki a szimbolikus-informális szférában.

A szimbolikus tartalmú régiók ugyanakkor az aktív regionalizmus vonatkozási egységei is lehetnek, elsősorban etnikai és vallásos szimbólumokkal felruházott régiók esetében: Baszkföld és Katalónia Spanyolországban, Korzika és Bretagne Franciaországban, Észak-Írország az Egyesült Királyságban stb. Ebben az esetben a mindennapi szimbolikus regionalizálások alappillére, a kultúra, nyelv és vallás mellett rendszerint a közös múlt, a közösen átélt történelem. Ez érvényes megállapítás nem csupán a föderalisztikus államok esetében (Németország), hanem erősen centralizált nemzetállamokban is, mint Franciaország vagy Románia, ahol konfliktusok forrása is lehet (Bretagne, Korzika).

\section{Összegzés}

Arra a kérdésre, hogy mi határozza meg a régiók létrejöttét és változását, az új regionális földrajzi kutatás kereteiben próbáltam választ találni. A megközelítés konstruktivista jellege kétségtelenül a választ a véletlentől a szükségszerüség irányába tolja el, és ezt annak ellenére, hogy a történelem fontos régióképződési tényező. Meg kell jegyeznünk, hogy itt nem valamilyen determinált, kauzális szükségszerüségről van szó, hanem különböző jellegü intézmények interszubjektíven létrehozott térprojekcióinak eredményeiről.

A fenti elemzési keret lehetővé tette számunkra, hogy Romániában megfelelőképpen értelmezhessük a normatív-formális regionalizáció folyamatát, úgy az 1998-ban létrehozott fejlesztési régiók, mint az 1968-ban véghezvitt megyésítés vonatkozásában. Ugyanakkor a szimbolikus-informális regionalizáció mechanizmusainak vizsgálata elvezetett a regionalizmus kérdéskörének teljesebb értékeléséhez, beleértve kapcsolódását a normatív-pozitív regionalizáláshoz. Ez különösen Romániában kiemelt kérdéskör, tekintettel arra, hogy a legaktívabb regionalizmus hordozója az erdélyi magyarság.

Anélkül, hogy polémiába keverednénk, végezetül ki szeretném hangsúlyozni, hogy az előadásban vázolt gondolatmenetnek megfelelően, a regionális kutatás egyik legfontosabb feladata abban rejlik, hogy a döntéshozók számára olyan ismereteket és információkat gyüjtsön és rendszerezzen, amelyek lehetővé teszik olyan döntések meghozatalát, amelyek a helyi és regionális közösségek esélyeit javíthatják. Ez megfelel a Derek Gregory által bevezetett „dialogical action” fogalmának, amely a regionális geográfia erős normatív és kritikai irányultságának igényét foglalja magában (Gregory 1998). Ez ugyanakkor implicit azt a képességet is tartalmazza, 
hogy a regionális tudomány a helyi és regionális közösségeket problémáik megoldására mobilizálhatja. Ennek megfelelően a térkutatás, mint regionális társadalomkutatás, csakis normatív és kritikai lehet.

\section{Irodalom}

Allen, J.-Massey, D.-Cochrane, A. (1998) Rethinking the Region. Routledge, London.

Benedek, J. (1998) Ideological constructs, social connections and geographical thought. - Wardenga, U.Wilczynski, W. (eds.) Religion, Ideology and Geographical Thought. WSP Kielce Studies in Geography 3. International Geographical Union, Kielce. 58-65. o.

Benedek J. (2000) A társadalom térbelisége és térszervezése. Risoprint, Kolozsvár.

Benedek J. (2001) Normativ-formális (intézményesült) regionalizálás és Románia intézményesült térszintjei. Ekéné Zamárdi I. (szerk.) 10 éves a Debreceni Egyetem Társadalomföldrajzi és Területfejlesztési Tanszéke. DE Területfejlesztési Tanszék, Debrecen. 159-170. o.

Benedek J. (2002) A földrajz térszemléletének hullámai. - Tér és Társadalom. 2. 21-40. o.

Benedek J. (2003) Tér és regionalizálás. - Süli-Zakar I. (szerk.) A terület-és településfejlesztés alapjai. Dialóg Campus, Budapest-Pécs. 85-124. o.

Benedek, J. (2008a) The emergence of new regions in transition Romania. - Scott, J. (ed.) De-coding New Regionalism. Shifting Socio-political Contexts in Central Europe and Latin America. Urban and Regional Planning Series. Ashgate, Aldershot. 233-246. o.

Benedek J. (2008b) Jelenkori térkoncepciók. - Bodó B. (szerk.) Európai Unió és regionális politika. Scientia Kiadó, Kolozsvár. 43-64. o.

Benedek, J.-Jordan, P. (2007) Administrative Dezentralisierung, Regionalisierung und Regionalismus in den Transformationsländern am Beispiel Rumäniens. - Mitteilungen der Österreichischen Geographischen Gesellschaft. 149 Jg., 81-108. o.

Blotevogel, H.H.-Heinritz, G.-Popp, H. (1987) Regionalbewusstsein-Überlegungen zu einer geographischlandeskundlichen Forschungsinitiative. - Informationen zur Raumentwicklung. 7/8. Bonn. 409-418. o.

Blotevogel, H.H. (1996) Auf dem Wege zu einer 'Theorie de Regionalität': die Region als Forschungsobjekt der Geographie. - Brunn, G. (rsg.) Region und Regionsbildung in Europa. Nomos Verlagsgesellschaft, Baden-Baden. 44-68. o.

Gregory, D. (1998) Explorations in critical human geography. Druckagentur Jürgen J.-Sause, Heidelberg.

Pohl, J. (1993) Regionalbewusstsein als Thema der Sozialgeographie. - Münchener Geographische Hefte. 70. Michael Lassleben, Kallmünz, Regensburg.

Pred, A. (1994) The Social Becomes the Spatial, the Spatial Becomes the Social: Enclosures, Social Change and the Becoming of Places in Skane. - Gregory, D.- Urry, J. (eds.) Social Relations and Spatial Structures. MacMillan, London.

Thrift, N. (1996) Spatial formations. SAGE Publications, London.

Weichart, P. (1996) Die Region-Chimäre oder Strukturprinzip sozialer Systeme? - Brunn, G. (ed.) Region und Regionsbildung in Europa. Nomos Verlagsgesellschaft, Baden-Baden. 25-43. o.

Werlen, B. (1997) Sozialgeographie alltäglicher Regionalisierungen. Franz Steiner Verlag, Stuttgart. 


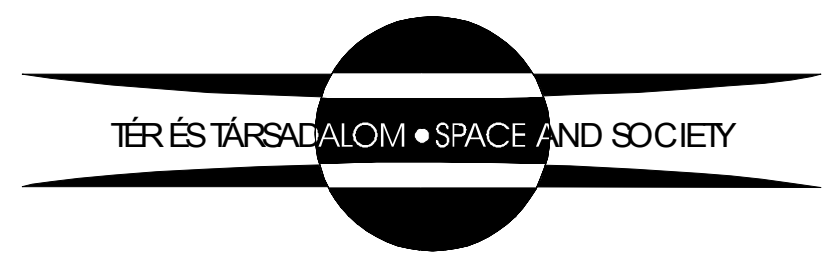

